Eur. J. Clin. Chem. Clin. Biochem.

Vol. 29, 1991, pp. 549-554

(C) 1991 Walter de Gruyter \& Co.

Berlin - New York

\title{
High Performance Liquid Chromatography Method for Rapid and Accurate Determination of Homocysteine in Plasma and Serum
}

\author{
By Birte Vester and K. Rasmussen \\ Klinisk-kemisk afdeling, Aarhus Kommunehospital, Aarhus, Danmark
}

(Received February 4/June 10, 1991)

Summary: Determination of homocysteine in plasma or serum for evaluation of cobalamin and folate deficiency is becoming an important diagnostic procedure. Accurate, rapid and low cost methods for measuring homocysteine are therefore required. We have improved an HPLC method and made it suitable for clinical application. The more important changes are the addition of an internal standard, mercaptopropionylglycine, and the use of a plasma/serum based calibration material. The method consists of the following steps: reduction of the sample with tri- $n$-butylphosphine, precipitation of proteins, derivatisation with ammonium 7-fluorobenzo-2-oxa-1,3-diazole-4-sulphonate, and HPLC separation followed by fluorescence detection. The linearity of the assays is established and the coefficient of variation is $3.0 \%$. Stability studies show that blood samples must be cooled or centrifuged immediately after venipuncture. The method is useful for evaluation of cobalamin or folate deficiency, especially in patients with normal or moderately depressed cobalamin or folate concentrations in blood.

\section{Introduction}

Homocysteine is intimately related to methionine metabolism. It constitutes a link between the transmethylation cycle where homocysteine is remethylated to methionine and the transsulphuration pathway which catabolises homocysteine to sulphate. Cobalamin and folate defiency results in impaired homocysteine remethylation and homocysteinaemia. The increasing interest in measuring homocysteine is related to its correlation to the cobalamin and folate status in patients deficient in one of these substances, and also to its presumed role in arteriosclerotic cerebrovascular diseases. Recently, these and other subjects related to homocysteine in plasma were reviewed by Ueland \& Refsum (1).

Our method can be used in any laboratory equipped with an HPLC system, and all reagents are commercially avalabile. Additon of mercaptopropionylglycine as an internal standard serves a double function in the assay - both as a control for the derivatisation reaction and as a standard for the size of the homocysteine peak.
About $70 \%$ of the homocysteine in plasma is reported to be bound to albumin $(1,2)$ and a variable amount is present as mixed disulphides. To measure the total homocysteine content (i.e., the sum of free homocysteine and disulphide-bound homocysteine) the plasma/serum sample is reduced with tri-n-butylphosphine before protein precipitation. The content of free homocysteine can be measured by performing the reduction step after protein precipitation.

\section{Materials and Methods}

Reagents

Ammonium 7-fluorobenzo-2-oxa-1,3-diazole-4-sulphonate was obtained from Wako (Kyoto, Japan); $D L$-homocysteine, mercaptopropionylglycine and tri-n-butylphosphine was from Sigma (St. Louis, MO, U. S. A.); cysteine and glutathione was from Merck (Darmstadt, Germany). All other chemicals were of analytical grade.

\section{Apparatus}

Separation and quantification were performed with a Merck Hitachi system (Pump 655A-12, LC Controller L-5000, fluorescence detector F-1050 and autosampler 655A-40) equipped 
with a Merck LiChrospher 100 RP-18 column $(4 \times 125 \mathrm{~mm}$, $5 \mu \mathrm{m}$ particles) protected by a Merck LiChrospher 100 RP-18 guard column $(4 \times 40 \mathrm{~mm}, 5 \mu \mathrm{m}$ particles $)$. The fluorescence intensitics were measured with excitation at $385 \mathrm{~nm}$ and emission at $515 \mathrm{~nm}$. The detection signal was recorded and the peak areas quantified with a Merck Hitachi D-2000 integrator.

\section{Chromatographic conditions}

We used the gradient procedures described by Araki \& Sako (2). Although our column and HPLC system differs from theirs and we observe shorter retention times, the procedures work satisfactorily.

Buffer A: $0.1 \mathrm{~mol} / \mathrm{l}$ acetate buffer, $\mathrm{pH} 4.0$, containing $20 \mathrm{ml} / \mathrm{l}$ methanol (prepared from $0.1 \mathrm{~mol} / 1$ acetic acid and $0.1 \mathrm{~mol} / 1$ sodiun acetate, approximately 600/1500).

Buffer B: $0.1 \mathrm{~mol} / \mathrm{l}$ phosphate buffer, $\mathrm{pH} 6.0$, containing 50 $\mathrm{ml} / 1$ methanol (prepared from $0.1 \mathrm{~mol} / 1$ sodium dihydrogen phosphate and $0.1 \mathrm{~mol} / \mathrm{l}$ disodium hydrogen phosphate, approximately $625 / 125$ ).

The buffers were filtered through a $0.45 \mu \mathrm{m}$ Millipore filter. The linear gradient was run from solvent $A$ to solvent $B$ over $12.5 \mathrm{~min}$ (then $2.5 \mathrm{~min} \mathrm{~B}$, a 3.0 min gradient back to $\mathrm{A}$, and $2.0 \mathrm{~min}$ A before the next injection) at a flow rate of $1.00 \mathrm{ml} /$ $\mathrm{min}$. We also used an isocratic system, which was run for 20 min with solvent $A$ at a flow rate of $1.00 \mathrm{ml} / \mathrm{min}$.

\section{Sample preparation}

Plasma samples were obtained from about $3 \mathrm{ml}$ of whole blood, which were collected in a Venoject tube containing EDTA, then immediately cooled on ice and centrifuged as soon as possible at $3000 \mathrm{~min}^{-1}(2000 \mathrm{~g})$ for $10 \mathrm{~min}$ at room temperature. Serum was prepared from whole blood which was left to clot for $1 / 2-3 / 4$ hour at room temperature, then centrifuged. Specimens were stored at $4^{\circ} \mathrm{C}$ for analysis on the same day. Storage for longer periods was at $-20^{\circ} \mathrm{C}$.

One hundred and fifty microlitres of plasma/serum (sample or calibration material) was mixed with $50 \mu \mathrm{l}$ of buffer/standard ( 0 or $0.2 \mathrm{mmol} / 1$ homocysteine, $0.2 \mathrm{mmol} / \mathrm{l}$ mercaptopropionylglycine in $0.1 \mathrm{~mol} / 1$ potassium borate, $\mathrm{pH} 9.5$, containing $2 \mathrm{mmol} / \mathrm{l}$ EDTA). Twenty microlitres of $100 \mathrm{ml} / 1$ tri- $n$-butylphosphine in dimethylformamide were added, and the reduction allowed to proceed for $30 \mathrm{~min}$ at $4^{\circ} \mathrm{C}$. Samples were then mixed with $125 \mu \mathrm{l}$ of $0.6 \mathrm{~mol} / \mathrm{l}$ perchloric acid, containing $1 \mathrm{mmol} / \mathrm{l}$ EDTA, left at room temperature for $10 \mathrm{~min}$, then centrifuged at $13000 \mathrm{~min}^{-1}(15500 \mathrm{~g})$ for $10 \mathrm{~min}$. One hundred microlitres were taken from the middle of the supernatant and mixed with $200 \mu \mathrm{l}$ of $2 \mathrm{~mol} / \mathrm{l}$ potassium borate, $\mathrm{pH} 10.5$, containing $5 \mathrm{mmol} / 1$ EDTA. Ammonium 7-fluorobenzo-2-oxa-1,3-diazole4-sulphonate solution $(100 \mu \mathrm{l})(1.0 \mathrm{~g} / \mathrm{l}$ of $2 \mathrm{~mol} / \mathrm{l}$ potassium borate, $\mathrm{pH} 9.5$ ) were added and the mixture incubated at $60^{\circ} \mathrm{C}$ for 60 min. After cooling in an ice bath, the samples were ready for HPLC. Ten microlitres of derivatised sample were used for each injection.

\section{Specimens}

Blood was obtained in the morning from 16 apparently healthy volunteers (eight men and eight women, aged 25-60 years). All were in a good nutritional state with a normal protein intake. None took drugs.

To test for possible interference from drugs, we measured homocysteine in plasma samples from 60 patients who had received various analgesic, antiepileptic, cardioactive, antipsychotic, antibiotic or antineoplastic drugs.

\section{Calibration and calculations}

A two point calibration line was obtained from triplicate analysis of a plasma/serum pool, and of this pool spiked with $\mathbf{5 0}$ $\mu \mathrm{mol} / \mathrm{l}$ homocysteine. A linear regression line, with the added homocysteine as the abcissa and the ratio between the area of the homocysteine peak and the mercaptopropionylglycine peak as the ordinate, was calculated to determine the slope of the calibration line. The concentration' of homocysteine in the samples was then determined by dividing the ratio between the area of the homocysteine peak and the mercaptopropionylglycine peak by the slope of the calibration line.

The plasma and serum pools were stored as aliquots at $-20^{\circ} \mathrm{C}$. The homocysteine and the mercaptopropionylglycine solutions were kept as $0.4 \mathrm{mmol} / 1$ aliquots at $-20^{\circ} \mathrm{C}$.

\section{Results and Discussion}

\section{Optimizing the assay conditions}

In this work we have improved a method published by Araki \& Sako (2) and made it more suitable for routine clinical use. The most important changes are the use of a plasma/serum pool for calibration instead of the buffer, and the addition of an internal standard. The use of a plasma/serum pool is necessary because the slope in the buffer calibration is less than in the plasma/serum pool calibration. The addition of mercaptopropionylglycine as an internal standard serves two purposes, as a control of the derivatisation procedure and as a direct standardisation of the size of the homocysteine peak. If the internal standard mercaptopropionylglycine is not added to the samples we find that the total imprecision of the method approximately doubles. Other technical changes are the use of $150 \mu \mathrm{l}$ of sample instead of the $500 \mu \mathrm{l}$ used by the previous method (2) and precipitation with perchloric acid instead of trichloroacetic acid. In our system, the use of perchloric acid instead of trichloroacetic acid gives a better separation of the peaks. As mentioned, we also tried to run the samples with an isocratic system to check whether HPLC systems not equipped with a gradient system can be used. The chromatograms obtained in this way with buffer A only are very similar to those from a gradient run, but we have not checked the stability and the durability of the column under these conditions for a longer period.

\section{Specificity}

Derivatisation of the plasma/serum samples with the thiol-specific reagent ammonium 7-fluorobenzo=2oxa-1,3-diazole-4-sulphonate (3) results in a simple chromatogram with a few well separated peaks as shown in figure 1 . The retention time for homocysteine is $3.2 \mathrm{~min}(\mathrm{SD}=0.032 \mathrm{~min}, \mathrm{CV}=1.0 \%$, $\mathrm{n}=100$ ) and for the internal standard $15.1 \mathrm{~min}$ (SD $=0.16 \mathrm{~min}, \mathrm{CV}=1.1 \%, \mathrm{n}_{\mathrm{i}}=100$ ). 


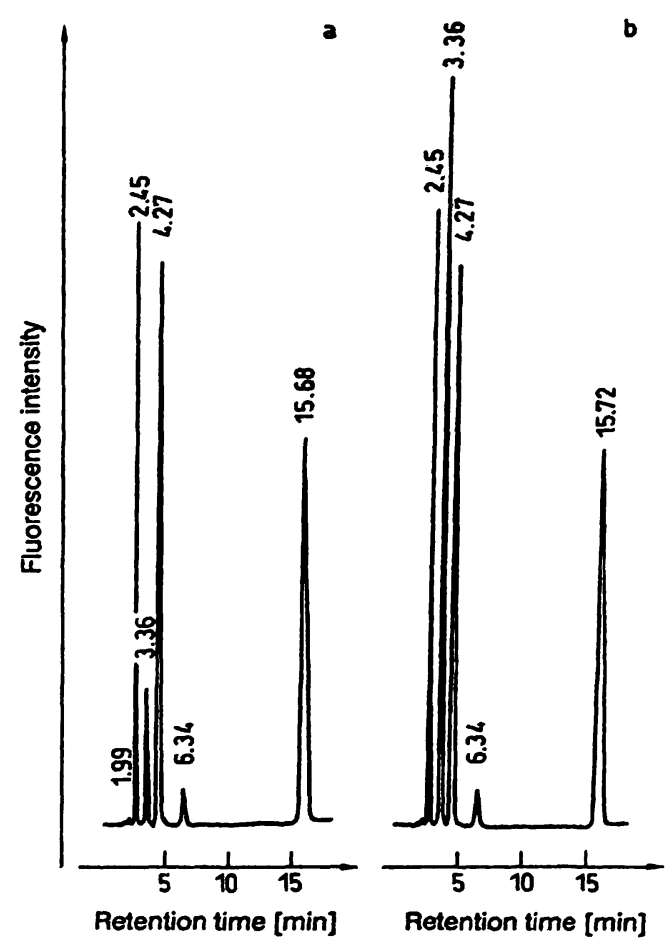

Fig. 1. HPLC chromatograms of ammonium 7-fluorobenzo-2oxa-1,3-diazole-4-sulphonate derivatised plasma with added internal mercaptopropionylglycine standard.

a) Plasma pool used for calibration.

b) Plasma pool with $50 \mu \mathrm{mol} / \mathrm{l}$ homocysteine added. The peaks at $3.36 \mathrm{~min}$ are the homocysteine and the peaks at 15.68 and 15.72 are the mercaptopropionylglycine standard. The peaks at $2.45 \mathrm{~min}$ and $6.34 \mathrm{~min}$ are cysteine and glutathione. The peaks at $4.27 \mathrm{~min}$ are assigned to cysteinyl-glycine (2).

The homocysteine peak was identified by adding homocysteine to the sample and observing an increase of the symmetrical well-defined peak. In the same way, we identified the peak with a retention time of about $2.4 \mathrm{~min}$ as cysteine, and the peak at about 6.3 min as glutathione. By comparison with the original work of Araki \& Sako (2) we tentatively identify the peak at about $4.3 \mathrm{~min}$ as cysteinyl-glycine.

When we analysed plasma samples from 60 patients who had received various drugs, the chromatograms did not reveal any interferences in the assay or the appearance of new peaks.

\section{Calibration}

Calibration lines prepared by the analysis of homocysteine in $0.2 \mathrm{~mol} / 1$ potassium borate, $\mathrm{pH} \mathrm{9.5,} \mathrm{or} \mathrm{in}$ a plasma pool showed different slopes $(15 \%$ difference). Calibration must therefore be performed with plasma/serum-based calibrators. This matrix effect could be due to the presence of proteins, ionic strength or some other species catalysing the derivatisation step. The variation of the slope in different plasmas was also investigated; the greatest variation was $4 \%$ and thus less than the difference between a plasma pool and the buffer.

\section{Recovery and linearity}

To investigate the recovery and linearity of the assay, we added different concentrations of homocysteine to both the plasma and serum pools. Homocysteine was added to a plasma pool so as to increase its concentration by $0,25,50,100,200,300,400$ and $500 \mu \mathrm{mol} / \mathrm{l}$. Linear regression analysis of the results gave $y=0.0220+0.0124 x$ with a correlation coefficient of 0.999 , where $y$ is the ratio of the homocysteine peak area divided by the mercaptopropionylglycine peak area and $x$ is the increase in homocysteine concentration. The same experiment with serum gave $y=0.1015+0.0136 x$ with a correlation coefficient of 1.000 . Addition of $0,5,10,25,50$ and $100 \mu \mathrm{mol} / 1$ to a plasma pool gave $\mathrm{y}=11.65+0.823 \mathrm{x}$ with a correlation coefficient of 0.999 , where $y$ is the ratio of the homocysteine peak area and $\mathrm{x}$ is the increase in homocysteine concentration.

Plasma and serum samples were also diluted 1.2, 1.5, 2, 3,6 and 12 times and plotted with $\mathrm{x}$ as the amount of sample and $y$ as the homocysteine peak area divided by the mercaptopropionylglycine peak area. The resulting line is slightly curved as expected from the dilution of the samples with a buffer with a $15 \%$ lower standardisation slope.

If a patient sample contains so much homocysteine that the chromatogram response goes off the scale (in our system more than $500 \mu \mathrm{mol} / \mathrm{l})$, the injection sample can be diluted and chromatographed again and recalculated by using the area of the mercaptopropionylglycine peak multiplied by the dilution factor.

\section{Detection limit}

The sensitivity of the method when defined as a signal to noise ratio $\geq 5$ is at least $0.3 \mu \mathrm{mol} / 1$ homocysteine. This value is in accordance with other HPLC methods for measuring homocysteine $(3,4)$. Araki \& Sako (2) did not state a limit of detection for measuring total homocysteine.

\section{Precision}

The total imprecision of the method was determined by dividing a plasma sample into aliquots and determining the homocysteine concentration of each aliquot in duplicate over a period of four weeks. The coefficient of variation was $3.0 \%$ (mean $=8.92$ 
$\mu \mathrm{mol} / \mathrm{l}$ homocysteinc, $\mathrm{n}=11$ ). The within-run component of imprecision was $2.3 \%$. Araki \& Sako (2) did not report values which are directly comparable. Furthermore, we divided a sample pool into ten aliquots which were assayed in one run. The coefficient of variation was $2.4 \%$ (mean $=10.94 \mu \mathrm{mol} / \mathrm{l}$ ). The major part of the variability is thus in the within-run imprecision, implying a low day-to-day variation.

The within-run imprecision of our method compares favourably with those reported for other HPLC assays for homocysteine in plasma, namely $2.9 \%$ (3), $5.0 \%(4)$, and $3.8 \%(5)$. This improvement is probably a result of the addition of the internal standard. Mercaptopropionylglycine has a high chemical resemblance to homocysteine although the retention time for mercaptopropionylglycine is considerably higher than for the homocysteine peak.

\section{Stability studies}

We investigated the effect of incubation of whole blood at room temperature before separation of plasma or serum from cells. As depicted in figure 2, a fresh blood sample left at room temperature without centrifugation will show a considerable increase in homocysteine concentration. This increase is linear for at least 4 hours and amounts to $9-10 \%$ per hour. The relative increase after 24 hours varies significantly from sample to sample. This increase in homocysteine concentration can be eliminated by centrifugation followed by pipetting of plasma/serum. After centrifugation and pipetting the concentrations of homocysteine in the samples are stable, even at room temperature, for at least 24 hours. Therefore, the blood samples must be cooled or centrifuged immediately after blood sampling.

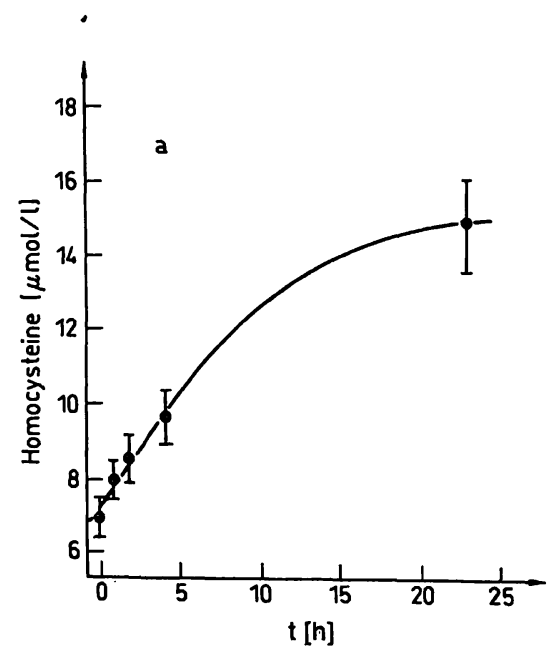

We stored plasma/serum samples at $-20^{\circ} \mathrm{C}$ for three months without any measurable change in the homocysteine concentrations. Furthermore, one sample was thawed and frozen nine times during one week and each time an aliquot was removed and frozen. When all samples were analysed in the same run, the homocysteine concentration wa's $9.64 \pm 0.19 \mu \mathrm{mol} / 1$ (mean $\pm \mathrm{SD}$ ) and the first and last values were 9.67 and 9.51 , respectively.

The samples are also very stable after derivatisation with ammonium 7-fluorobenzo-2-oxa-1,3-diazole-4sulphonate. They can be stored at $4{ }^{\circ} \mathrm{C}$ for several weeks. The samples may turn yellow because ammonium 7-fluorobenzo-2-oxa-1,3-diazole-4-sulphonate is light sensitive. However, this does not seem to cause any problems in the assay, but as a precaution we kept the ammonium 7-fluorobenzo-2-oxa-1,3-diazole-4-sulphonate solution in a cold and dark place until use.

We did not filter the samples before injection into the column because we found it more economical (both in materials - the cost of one guard column equals the cost of 20 filters - and working hours) to change the small guard columns after about 75 sample injections.

The high increase of homocysteine in plasma/serum when blood samples are left at room temperature is an interesting problem. Cooling of the blood sample followed by incubation at room temperatures does not stop the increase of homocysteine in plasma/ serum. We measured the homocysteine concentration in haemolysates of blood and in isotonic $\mathrm{NaCl}$ incubated with the residue of blood samples after removal of plasma. These preliminary experiments indicate that the homocysteine increase stems from a produc-

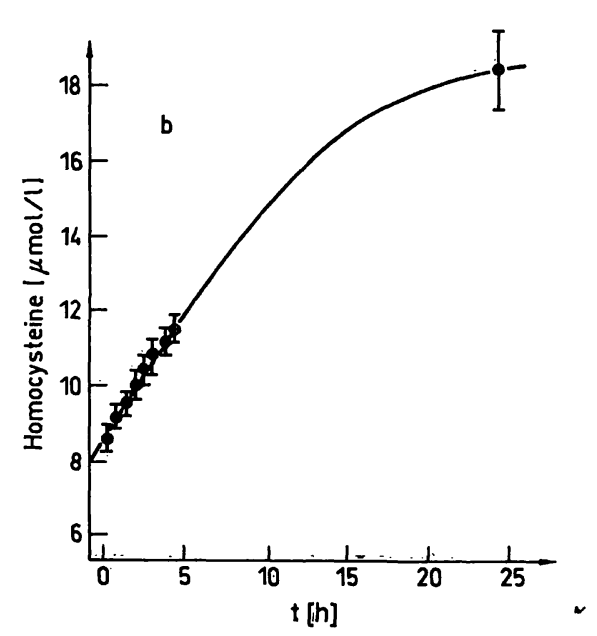

Fig. 2. Incubation of whole blood at room temperature before separation of plasma or serum from cells. The increases of homocysteine when measured in plasma (a) or serum (b) specimens, are depicted. The results are the average of experiments on five subjects. The error bars indicate \pm SEM. 


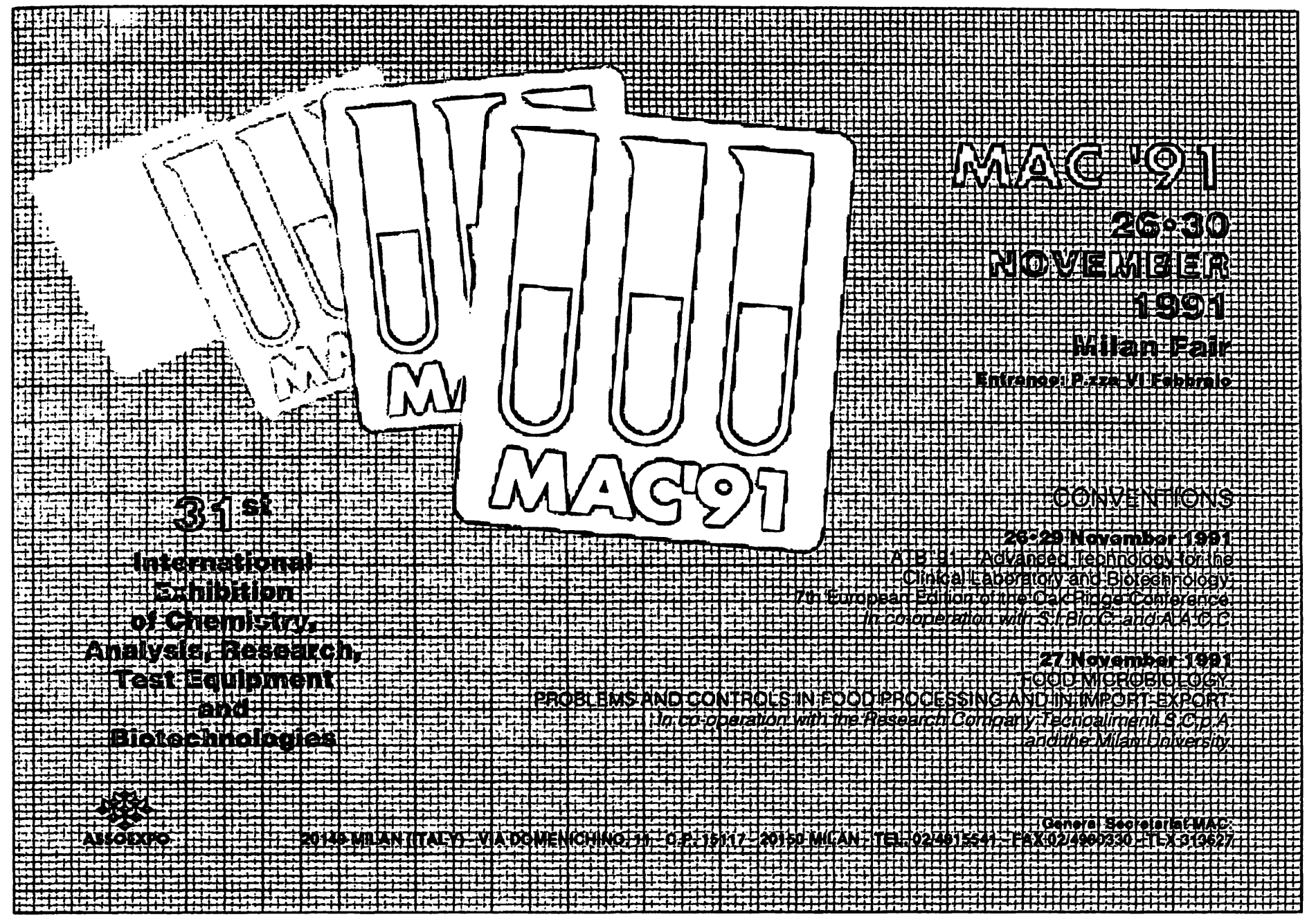

Am Institut für Medizinische Chemie und Biochemie der Medizinischen Fakultät gelangt eine Planstelle eines/einer

\section{Ordentlichen Universitätsprofessors/Universitätsprofessorin für Medizinisch-Analytische Chemie}

zur Besetzung.

Anstellungserfordernisse sind ein in- oder ausländisches facheinschlägiges Doktorat, eine in- oder ausländische facheinschlägige Lehrbefugnis (venia docendi oder eine gleichzuhaltende wissenschaftliche Befähigung) und der Nachweis der pädagogischen Eignung.

Ein Schwerpunkt des Institutes für Medizinische Chemie und Biochemie liegt in der Pteridinforschung. Bewerber/Bewerberinnen sollen durch hervorragende Forschungsleistungen auf dem Gebiet der medizinrelevanten Pteridinforschung ausgewiesen sein und eine besondere Bereitschaft zur Zusammenarbeit im Rahmen der interdisziplinären Kooperation zwischen theoretischen und klinischen Institutionen der Medizinischen Fakultät haben.

Von dem/der künftigen Universitätsprofessor/Universitätsprofessorin wird erwartet, daß er/sie das Gesamtgebiet der Medizinischen Chemie gemeinsam mit dem Ordentlichen Universitätsprofessor für Medizinische Chemie in der Lehre betreut.

Bewerbungen mit den üblichen Unterlagen (Lebenslauf, wissenschaftlicher Werdegang, bisherige Lehrtätigkeit zum Nachweis der pädagogịschen Eignung, Aufstellung.der Veröffentlichungen, internationale Kooperationen usw.) sind bis spätestens 30. September 1991 an den Dekan der Medizinischen Fakultät der Leopold-Franzens-Üniversität Innsbruck, Univ.-Prof. Dr. E. Bodner, Innrain 52, A-6020 Innsbruck, $\mathrm{zu}$ richten.

O. Univ.-Prof. Dr. E. Bodner Dekan 


\section{Concise Encyclopedia Biochemistry}

\section{Second Edition,}

revised and expanded by Thomas Scott and Mary Eagleson

1988. $17 \mathrm{~cm} \mathrm{x} 24 \mathrm{~cm}$. 650 pages. Hardcover. DM 148,-; approx. US $\$ 89.00$

ISBN 3110116251

The only single work of its kind in English, the Concise Encyclopedia of Biochemistry provides a comprehensive, yet compact, source of biochemical data and information for the researcher, teacher, and student.

Following a five-year program of collecting and editing new material, as well as the revision of existing entries, the author-editors and the publishers are pleased to announce the new expanded Second Edition of this valuable reference work.

Major entries concerning the latest developments in DNA structure, synthesis, sequencing, binding proteins and methods, oncogenes, lymphokines and other newly discovered regulatory peptides, structural proteins, inositol phosphates, and protein kinases have been added. Graphic illustration has been given high priority, so that regulatory processes, transport, subcellular structures, etc. are abundantly and clearly illustrated.

The coverage of plant biochemistry has also been greatly expanded. Another new addition is a section on buffers which will be useful to anyone involved in laboratory work. Because of its comprehensiveness and multidisciplinary nature, we are sure that you will find it an indispensable reference tool.

Special features of this edition include:

- Approximately 4,500 entries

O Up-to-date, comprehensive

- Coverage of medical, animal, microbial, plant, and physical biochemistry, natural products, molecular biology, molecular genetics, and biotechnology

- Hundreds of illustrations, including structural formulas, schemes, and metabolic pathways

- Over 100 tables

- Modern terminology based on standard sources, e. g., IUB Enzyme Nomenclature

- Standard biochemical abbreviations

- Extensive cross references with synonyms provided

- Literature references are cited to aid the reader in locating original sources

Potential audience: blochemists, clinical biochemists, clinical chemists, medical researchers, clinicians, plant scientists, experimental biologists, lecturers and students of the life sciences. 


\section{The Roots of Modern Biochemistry}

\section{Fritz Lipmann's Squiggle and its Consequences}

Editors Horst Kleinkauf, Hans von Döhren, Lothar Jaenicke

$1988.17 \mathrm{~cm} \times 24 \mathrm{~cm}$. XII, 988 pages. Numerous illustrations.

Hardcover. DM 448,-; approx. US \$263.00 ISBN 3110115859

A Fritz Lipmann dedicatory volume, originating from the Memorial Meeting held in Berlin-Dahlem in 1987, presenting the major aspects of modern biochemistry and their development in 90 essays. The Warburg/Meyerhof era, the time of emigration and postwar science are revived. Contemporaries and coworkers together with other outstanding scientists describe the state of biochemistry in major fields: as it was, as it is now, and where it will be going. At the same time this volume is a reference book on Fritz Lipmann, the outstanding biochemist, and life scientist, who considered his concept of the energy-rich bond, symbolized by the squiggle, as his major achievement.

\section{From the Contents}

Fritz Lipmann 1899-1986 • Biochemistry Comes of Age •

Molecular Biology Sharpens its Tools - Functional Dynamics:

The Squiggle-Symbol of Bioenergetics; Molecular Recognition and Communication - Evolution - List of Contributors - Lipmann's Coworkers at Massachusetts General Hospital, Boston, and the Rockefeller Unniversity, New York · Fritz Lipmann: Bibliography 1924-1985 · Author Index · Subject Index 


\section{Das Arbeitsprinzip des}

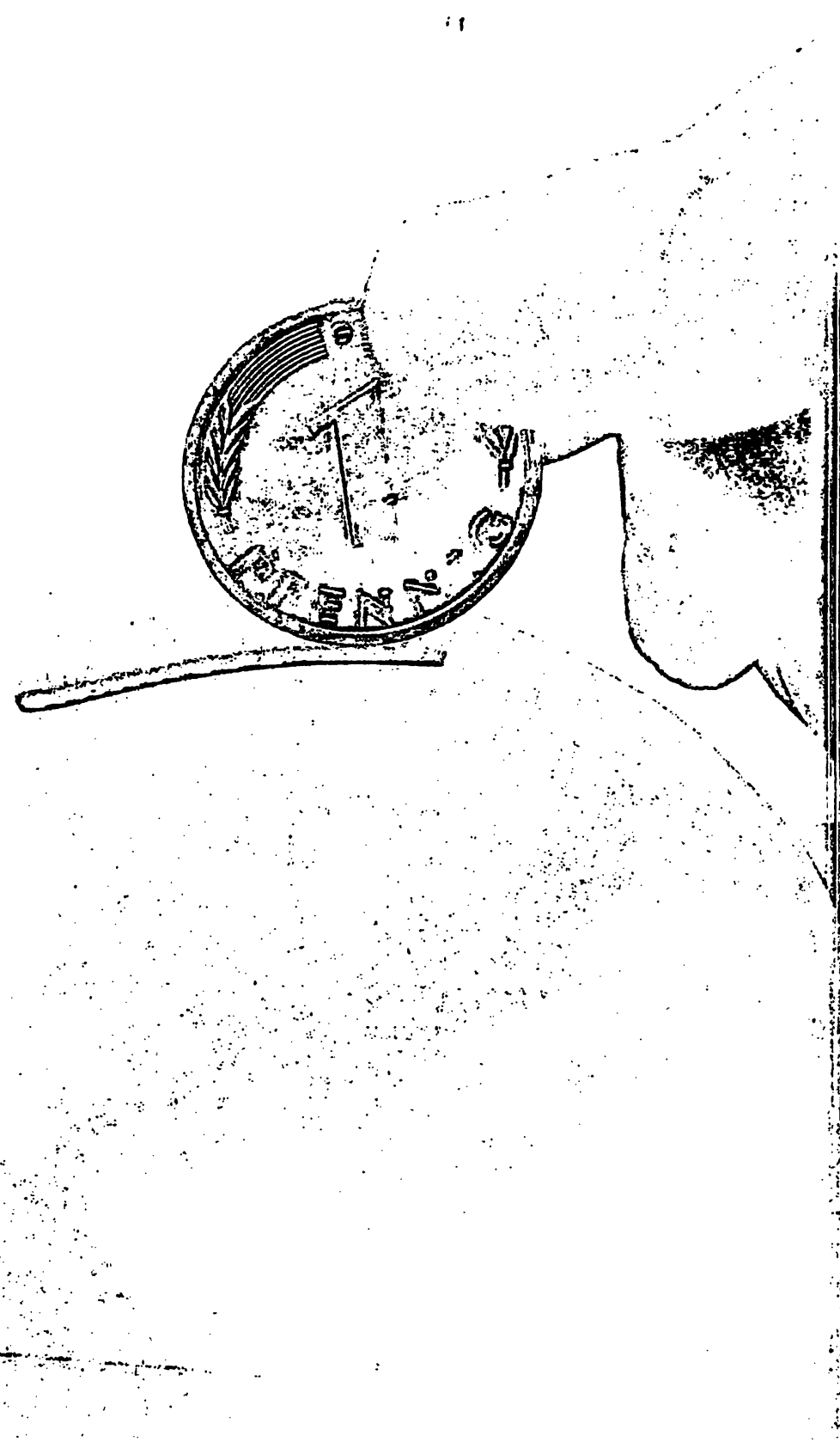

.

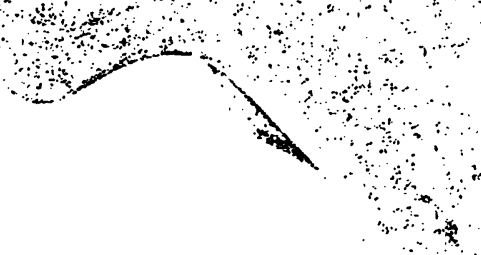

a. 


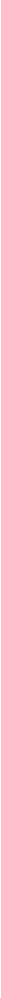

Nur $1 \mu \mathrm{l}$ Serum pro Bestimmung ist erforderlich mehr nicht! Weniger Serum bedeutet auch weniger Reagenz. Jahr für Jahr fallen in der Bundesrepublik durch klinisch-chemische Tests gut und gern 250.000 Liter Reagenzien an. 10 Tanklastzüge! Diese Menge muß nicht nur gekauft werden, sondern auch ihre Entsorgung wird künftig durch schärfere Vorschriften mit Sicherheit kostspieliger. Der TECHNICON CHEM 1 von Bayer Diagnostic kann die anfallenden Mengen um 95\% senken! Das ist neuer Umweltrekord! Die einzigartige Kapselchemie macht dies möglich. Die zu untersuchenden Patientenproben sind - wie das Gelbe im $\mathrm{Ei}$ - von einem flüssigen Film umgeben, also eingekapselt. So ist eine gegenseitige Beeinflussung der Proben ausgeschlossen und die Richtigkeit der Ergebnisse ist gewährleistet. Es zahlt sich aụs, mehr über den TECHNICON CHEM 1 zu wissen! Wir informieren Sie gerne. Schreiben Sie uns bitte oder senden Sie ein Fax an:

Bayer Diagnostic $\mathrm{GmbH}$

Weißenseestraße 101

8000 München 90

Telefax 0 89/6 9927-127 


\section{The Biologic $\mathbb{R}$ ole of Delhydroepiandrosterome (DHEA)}

\section{Editors M. Y. Kalimi, W. Regelson}

1990. $17 \mathrm{~cm} \times 24 \mathrm{~cm}$. VIII, 450 pages. Numerous illustrations and tables. Hardcover DM 340,-; approx. US \$220.00 ISBN $311012243 \mathrm{X}$

$D H E A$ is a native steroid that declines with progressive age, and is found in the brain at concentrations equal to that in the adrenal cortex. DHEA acts as a precursor steroid and/or a buffer hormone that alters state dependency by interacting with other hormones.

There is a growing interest in DHEA's clinical place in atherosclerosis, hypertension, memory disorders, fat mobilization, and cancer prevention treatment.

Experts from around the world have contributed to this volume. They explain DHEA's broad action and it's potential relevance to clinical disease. 
tion of homocysteine or a conversion of homocysteine derivatives to homocysteine in the blood cells. This matter will be further investigated.

\section{Practicability}

Whether it is preferable to use plasma or serum is very dependent on the laboratory routines. We prefer to use plasma, because although serum can be used if the reference range for healthy individuals is adjusted to it (tab. 1), it is impractical to keep control of the clotting time and the following centrifugation. The plasma method requires "a glass of ice at the bedside" and although this is inconvenient it is manageable.

Tab. 1. Homocysteine concentration in $\mu \mathrm{mol} / \mathrm{l}$, analysed in plasma and serum obtained from the same venipuncture. $\mathrm{n}=8$ for both men and women.

\begin{tabular}{lrrl}
\hline & mean & SD & range \\
\hline Plasma & & & \\
men & 9.8 & 1.6 & $7.8-11.9$ \\
women & 6.8 & 1.2 & $5.5-8.4$ \\
Serum & & & \\
men & 10.8 & 1.6 & $8.7-13.0$ \\
women & 7.6 & 1.2 & $5.8-9.1$ \\
\hline
\end{tabular}

About 50 tubes (calibrators +22 samples in duplicate) can easily be processed in one working day and the samples can be analysed overnight. Use of the assay for six months provided it to be a robust and effective method, suitable for routine analysis.

We also used the method to determine free homocysteine in two samples (by precipitating the proteins before reduction with tri $n$-butylphosphine). The samples showed a free homocysteine content of $1.6 \mu \mathrm{mol} / 1$ and $1.7 \mu \mathrm{mol} / \mathrm{l}$ homocysteine $(6.1 \mu \mathrm{mol} / \mathrm{l}$ and 6.9 $\mu \mathrm{mol} / 1$ in total homocysteine) which compare well with the values reviewed by Ueland \& Refsum (1).

\section{Analysed blood samples}

Plasma/serum homocysteine concentrations were measured in blood samples from 16 apparently healthy volunteers. The plasma and the serum were obtained from the same venipuncture, and the homocysteine values were consistently higher (in average $10 \%$ ) for all serum samples ( $p<0.005$, Wilcoxon test for pair differences). Most of this difference can be attributed to the different treatment of the blood samples, plasma samples being cooled immediately, whereas serum samples are left to clot at room temperature for $1 / 2-3 / 4 \mathrm{~h}$ before centrifugation.

The homocysteine range has been reported to differ between men and women (as illustrated by the values below) but also to be age-dependent; for further details see 1. c. (1). In general, men seem to have higher concentrations of homocysteine than women, while older people have higher concentrations than younger people. Our data, which are summarized in table 1 , support this difference between the homocysteine values in men and women ( $p<0.005$, Wilcoxon test for two samples). Our values are a little higher than those reported by Araki \& Sako (2) who found $6.53 \pm 1.08$ $\mu \mathrm{mol} / 1$ homocysteine (mean $\pm \mathrm{SD})$ for men $(\mathrm{n}=20)$, and $5.71 \pm 1.20$ for women $(\mathrm{n}=15)$, while they are a little lower than the values reported by Brattström et al. (6) who reported $12.1 \pm 4.0$ for men $(n=22)$ and $8.9 \pm 1.0$ for women $(n=10)$. Even higher values $(7.2-21.7 \mu \mathrm{mol} / 1$ homocysteine (mean $\pm 2 \mathrm{SD}$ ), $20 \%$ higher in males than in females) have been reported for serum samples (7). These differences can probably be explained by the different handling of the blood samples before separation of plasma and serum from cells and the various analytical methods employed.

Finally, in plasma samples of two patients with depressed concentrations of erythrocyte folate (188 and $301 \mathrm{nmol} / 1$ respectively; reference range: $400-1200$ $\mathrm{nmol} / \mathrm{l}$ ) we found increased concentrations of plasma homocysteine, namely, 60.6 and $48.1 \mu \mathrm{mol} / \mathrm{l}$.

\section{Conclusion}

We have improved a method for measuring total homocysteine in plasma and serum. The method uses only commercially available reagents and requires only a standard HPLC apparatus equipped with a fluorescence detector in addition to normal laboratory equipment. The addition of an internal standard ensures good precision, accuracy and performance. The analysis is robust, fast and inexpensive and is now suitable for routine use in the clinical laboratory.

\section{Acknowledgement}

We thank Dr. E. Mortensen for helpful discussions, Dr. $H$. Jelert for his assistance in obtaining the blood samples from patients together with information about disease and drug intake, and $A$. L. Christensen for skilful technical assistance. 


\section{References}

1. Ueland, P. M. \& Refsum, H. (1989) Plasma homocysteine, a risk factor for vascular disease: Plasma levels in health, disease, and drug therapy. J. Lab. Clin. Med. 114, 4733501.

2. Araki, A. \& Sako, Y. (1987) Determination of free and total homocysteine in human plasma by high-performance liquid chromatography with fluorescence detection. J. Chromatogr. $422,43-52$.

3. Refsum, H., Ueland, P. M. \& Svardal, A. M. (1989) Fully Automated Fluorescence Assay for Determining Total Homocysteine in Plasma. Clin. Chem. 35, 1921-1927.

4. Jacobsen, D. W., Gatautis, V. J. \& Green, R. (1989) Determination of Plasma Homocysteine by High-Performance Liquid Chromatography with Fluorescence Detection. Anal. Biochem. 178, 208-214.
5. Brattström, L., Israelsson, B., Jeppsson, J. O. \& Hultberg, B. (1988) Folic acid - an innocuous means to reduce plasma homocysteine. Scand. J. Clin. Lab. Invest. 48, 215-221.

6. Brattström, L., Israelsson, B., Norrving, B., Berqvist, D., Thörne, J., Hultberg, B. \& Hamfèlt, A. (1990) Impaired homocysteine metabolism in early-onset cerebral and peripheral occlusive arterial disease - effects of pyridoxine and folic acid treatment. Atherosclerosis $81,51-60$.

7. Stabler, S. P., Marcelli, P. D., Podell, E. R. \& Allen, R. H. (1987) Quanitation of total homocysteine, total cysteine, and methionine in normal serum and urine using capillary gas chromatography-mass spectrometry. Anal. Biochem. 162, $185-196$.

Birte Vester, Ph. D.

University Department of Clinical Chémistry

Skejby Hospital

DK-8200 Aarhus N 